\title{
CORRELATION AMONG SLEEP DURATION, BLOOD PRESSURE, AND BLOOD GLUCOSE LEVEL OF MORANGAN PEOPLE, SINDUMARTANI, NGEMPLAK, SLEMAN
}

\section{Gregorius Bhaskara Wikanendra*), Rita Suhadi, Christianus Heru Setiawan, Dita Maria Virginia, Phebe Hendra, Fenty}

\author{
Faculty of Pharmacy, Sanata Dharma University, Paingan, Maguwoharjo, Depok, Sleman, \\ Yogyakarta, 55282, Indonesia
}

Received February 03, 2020; Accepted April 17, 2020

\begin{abstract}
Sleep deprivation is a risk factor for cardiovascular and metabolic diseases. There was a high prevalence of high blood pressure and type 2 diabetes in Morangan, Yogyakarta Province. This study aims at studying the correlation between sleep duration, systolic blood pressure and fasting blood glucose levels of people in Morangan. This study was a cross-sectional study conducted in cooperation with a public health care program for people in Morangan. Data collection was done using a questionnaire and health screening procedure during the public health care program. Collected data were covering aspects of systolic blood pressure, fasting blood glucose, sleep duration, and sleep habit. There was a high prevalence of high systolic blood pressure $(>130 \mathrm{mmHg} ; 66.04 \%)$ and high fasting blood glucose level (>100mg/dL; 39.62\%) in Morangan people. There was a significantly positive correlation between sleep duration and systolic blood pressure (p:0.024; r:0.31) but no significant correlation between sleep duration and fasting blood glucose level. The major contributing habits towards sleep deprivation were caffeine consumption and medium pre-sleep routine. The result of this research will provide help in designing an education program for people of Morangan in preventing and treating high blood pressure and type 2 diabetes.
\end{abstract}

Keywords: blood glucose; blood pressure; Morangan; sleep duration.

\section{INTRODUCTION}

Sleeping is a physiological process important to human which in recent years, its duration and quality are declining. This decline in sleep duration and quality causes an increase in sleep deprivation related diseases. Sleep deprivation is a risk factor for cardiovascular and metabolic diseases (Becker et al., 2015; Wang et al., 2015). A metaanalysis study shows that there is a strong connection between sleep deprivation and hypertension (Wang et al., 2015). A previous study also shows a fact that the majority of type 2 Diabetes patients in puskesmas (healthcare center) of Ngesrep Semarang also suffers from sleep deprivation (Simanjutak et al., 2018).

Healthy sleep is composed of several components which include duration, quality, timing and lack of sleep disorder. Disturbing factors towards healthy sleep include consumption of caffeine prior to sleep, lack of physical activity, exposure to artificial light and screens at night and inconsistent bedtime routine. Sleep deprivation is generally associated with fatigue, sleepiness, and other health and safety problems (Chaput et al., 2018).

While lack of sleep is commonly associated with increasing health risks, excess of sleep in the elderly is associated with

*Corresponding author: Gregorius Bhaskara W

Email: gregorius.bhaskara@gmail.com 
mortality and morbidity (Hirshkowitz et al., 2015). The ideal sleep duration varies from person to person and among different age groups. The National Sleep Foundation suggests that for an adult of 26-64 years of age, the ideal sleep duration is between 7-9 hours while for an elderly person above 65 years old, the ideal sleep duration is between 7-8 hours daily (Chaput et al., 2018).

In a research conducted in 2018 by the Ministry of Health of Indonesia, the finding revealed an increasing prevalence in both type 2 DM and cardiovascular disease since 2013 in the province of Yogyakarta (DIY) (Badan Penelitian dan Pengembangan Kesehatan Kementrian Kesehatan RI, 2018). This result agrees with the previous research which reports a high prevalence of type $2 \mathrm{DM}$ and hypertension (10.4\% and $39.8 \%$ respectively) in Sleman (Suhadi et al., 2017). One of the villages used for sampling was Morangan village, Ngemplak, Sleman, DIY. The majority of Morangan people consisted of elderly yet they lacked proper knowledge towards the treatment and prevention of type 2 DM and hypertension.

Morangan village was the subject of United Board Project Grant in 2019-2020 entitled Inter-Professional Collaboration to Enhance Student Collaboration and Public Health Care. This project provided an opportunity for research and collaboration to study the correlation between sleep duration, blood pressure and blood glucose level of Morangan people. The result of this study was expected to be used to provide better health care towards people of Morangan.

\section{METHODS}

This study was a cross-sectional study conducted in Morangan, Ngemplak, Sleman, DIY. Data were collected on $10^{\text {th }}$ of August, 2019 during the United Board InterProfessional Collaboration to Enhance Student Collaboration and Public Health Care program. The subjects were chosen by purposive sampling method and data were collected from 53 respondents. This study had been granted an ethical clearance by the Faculty of Medicine, Duta Wacana Christian
University Ethical Committee with clearance number of 1077/C.16/FK/2019.

Respondents were asked to fill out an informed consent form before data collection began. Systolic blood pressure was measured using an Omron ${ }^{\circledR}$ automatic blood pressure monitor. Fasting blood glucose level was measured using Easytouch ${ }^{\circledR}$ blood glucose monitor. Information regarding sleep duration and sleep habits was collected using a validated questionnaire. The questionnaire used in this study was derived from the Sleep Quality Questionnaire by Girschk et al., (2012) and modified to ensure its validity to be used in Morangan context (Girschik et al., 2012). Data collection was done by a group of trained medical personnel.

Data on sleep duration gathered from the questionnaire were then divided into ideal and non-ideal categories based on the age groups. The collected data were then analyzed using SPSS for their descriptive characteristics and for the correlation among sleep duration, systolic blood pressure, and blood glucose level. The analysis was conducted using an independent $\mathrm{T}$-test for the internal difference in systolic blood pressure and fasting blood glucose level followed by a correlation test between groups using Pearson correlation.

\section{RESULTS AND DISCUSSION}

As can be seen in table 1, the majority of the respondents was predominantly female compared to male $(67.69 \%$ to $32.31 \%$ respectively). Most respondents were less than 65 years old $(83.02 \%)$. More than half of them had an ideal sleep duration (52.83\%). The majority of respondents in this study had systolic blood pressure above $130 \mathrm{mmHg}$ $(66.04 \%)$ and fasting blood glucose less than $100 \mathrm{mg} / \mathrm{dL}$ (60.28\%). Systolic blood pressure and fasting blood glucose measurement conducted in this study served as both data collection and screening processes for high blood pressure and type 2 diabetes. There was an increasing prevalence of high systolic blood pressure (from $39.8 \%$ to $66.04 \%$ ) and high fasting blood glucose (from $10.4 \%$ to $39.62 \%$ ) compared to a previous study conducted towards the same population in 2017 (Suhadi 
et al., 2017). Although this measurement was only done as a screening, this result showed that people in Morangan village was in dire need of treatment and education for high blood pressure and type 2 diabetes.

As can be seen in table 2, statistical analysis of systolic blood pressure shows a significant increase $(\mathrm{p}=0.024)$ in people without an ideal sleeping duration (147.8 \pm $27.55 \mathrm{mmHg}$ ) compared to people with an ideal sleeping duration $(142.79 \pm 25.9 \mathrm{mmHg})$. This result supports the notion that there is a positive correlation $(\mathrm{p}=0.024 ; \mathrm{r}=0.31)$ between non-ideal sleep duration with an increase in systolic blood pressure as stated in table 3. This result is reflective of previous finding which states that there is an increasing risk of developing hypertension in insomniac patients (St-Onge et al., 2016). Ideal sleep duration is essential in maintaining cardiovascular health. A study by Aggarwal (2013) states that lack of sleep is associated with increasing prevalence of stroke, myocardial infarct, and congestive heart failure while the excess of sleep, on the other hand, is associated with an increasing prevalence of coronary artery disease and angina (Aggarwal et al., 2013).

Table 1. Characteristics of Morangan people

\begin{tabular}{cccc}
\hline & & $\mathrm{N}$ & Percentage \\
\hline Gender & Male & 16 & $30.19 \%$ \\
\hline Age & Female & 37 & $69.81 \%$ \\
\hline Sleep Duration & $\leq 65$ years old & 44 & $83.02 \%$ \\
\hline & $>65$ years old & 9 & $16.98 \%$ \\
\hline Systolic Blood Pressure & Ideal & 28 & $52.83 \%$ \\
\hline & Non-Ideal & 25 & $47.17 \%$ \\
\hline Fasting Blood Glucose & $\leq 130 \mathrm{mmHg}$ & 18 & $33.96 \%$ \\
\hline & $>130 \mathrm{mmHg}$ & 35 & $66.04 \%$ \\
\hline
\end{tabular}

Table 2. Comparison between ideal and non-ideal sleep duration

\begin{tabular}{lllc}
\hline & Ideal Sleep Duration & Non-Ideal Sleep Duration & P \\
\hline Systolic Blood Pressure (mmHg) & $142.79 \pm 25.9$ & $147.8 \pm 27.55$ & 0.024 \\
\hline Fasting Blood Glucose (mg/dL) & $97.5 \pm 16.39$ & $99.4 \pm 17.33$ & 0.835 \\
\hline
\end{tabular}

Table 3. Correlation among sleep duration, systolic blood pressure, and fasting blood glucose

\begin{tabular}{lrc} 
Parameter & $\mathrm{r}$ & $\mathrm{p}$ \\
\hline Sleep Duration and Systolic Blood Pressure & 0.31 & 0.024 \\
\hline Sleep Duration and Fasting Blood Glucose & -0.029 & 0.835 \\
\hline Systolic Blood Pressure and Fasting Blood Glucose & 0.291 & 0.034 \\
\hline
\end{tabular}

Statistical analysis of fasting blood glucose displays no significant correlation between fasting blood glucose and sleeping duration ( $\mathrm{p}=0.835 ; \mathrm{r}=-0.029)$ as stated in table 3 . This result was in contrast with the result of previous study which showed that there was an additive effect between losses of sleep and impaired fasting blood glucose level (Lou et al., 2014). Lack of sleep causes a dysregulation of leptin and ghrelin which produces higher appetite and fasting blood glucose (Morselli et al., 2010). This lack of correlation can be partially attributed to a lack of difference $(\mathrm{p}=0.835)$ between people with ideal sleep duration $(97.5 \pm 16.39 \mathrm{mg} / \mathrm{dL})$ and the ones with non-ideal sleep duration (99.4 \pm 
$17.33 \mathrm{mg} / \mathrm{dL}$ ) as can be seen in table 2 . Even though the people of Morangan showed a high prevalence of high fasting blood glucose $(39.62 \%)$, the majority of them $(60.28 \%)$ showed fasting blood glucose less than $100 \mathrm{mg} / \mathrm{dL}$.

A positive correlation $(\mathrm{p}=0.034$; $\mathrm{r}=0.291)$ is also found between systolic blood pressure and fasting blood glucose level as stated in table 3. Hypertension and type 2 diabetes share several pathophysiological mechanisms including obesity which causes oxidative stress and chronic low-grade inflammation leading to inappropriate activation of renin-angiotensin-aldosterone system and insulin resistance (Lastra et al., 2014). The sleep habits of Morangan people can be seen in table 4 . The majority of the respondents slept for less than 8 hours daily and woke up earlier than 6 o'clock in the morning without any noticeable difference between workday and holiday. Their activities before sleeping was almost equally divided between light activities (43.40\%) and moderate activities $(56.60 \%)$. The majority of the respondents used bed for sleeping $(75.47 \%)$. More than half of the population consumed caffeinated drink prior to sleeping $(58.49 \%)$ with the most common beverages of tea and coffee. There was only a minuscule amount of the population who smoked as a pre-sleep routine and no one routinely consumed alcohol. Most of the respondents slept with lights off and without any disturbing noise. The majority slept in the bedroom with their companion as their sleep habit and most did not have a television in their bedroom.

Table 4. Sleep habits of Morangan people

\begin{tabular}{|c|c|c|c|}
\hline & & $\mathrm{N}$ & Percentage \\
\hline \multirow[t]{2}{*}{ Sleep duration on a working day } & $<8$ Hours & 37 & $69.81 \%$ \\
\hline & $>8$ Hours & 16 & $30.19 \%$ \\
\hline \multirow[t]{2}{*}{ Sleep duration on holiday } & $<8$ Hours & 38 & $71.70 \%$ \\
\hline & $>8$ Hours & 15 & $28.30 \%$ \\
\hline \multirow[t]{2}{*}{ Waking schedule on a working day } & $<06.00$ a.m & 51 & $96.23 \%$ \\
\hline & $>06.00$ a.m & 2 & $3.77 \%$ \\
\hline \multirow[t]{2}{*}{ Waking schedule on holiday } & $<06.00$ a.m & 51 & $96.23 \%$ \\
\hline & $>06.00$ a.m & 2 & $3.77 \%$ \\
\hline \multirow[t]{2}{*}{ Sleep schedule on a working day } & $<22.00$ p.m & 39 & $73.58 \%$ \\
\hline & $>22.00$ p.m & 14 & $26.42 \%$ \\
\hline \multirow[t]{2}{*}{ Sleep schedule on holiday } & $<22.00$ p.m & 39 & $73.58 \%$ \\
\hline & $>22.00$ p.m & 14 & $26.42 \%$ \\
\hline \multirow[t]{2}{*}{ Activity before sleeping } & $\begin{array}{l}\text { Light activity, reading, praying, } \\
\text { listening to music }\end{array}$ & 23 & $43.40 \%$ \\
\hline & $\begin{array}{l}\text { Watching movie, studying, having a } \\
\text { conversation }\end{array}$ & 30 & $56.60 \%$ \\
\hline \multirow[t]{2}{*}{ Activity on bed } & Sleeping & 40 & $75.47 \%$ \\
\hline & Others & 13 & $24.53 \%$ \\
\hline \multirow[t]{2}{*}{ Caffeine consumption before sleeping } & Yes & 31 & $58.49 \%$ \\
\hline & No & 22 & $41.51 \%$ \\
\hline
\end{tabular}




\begin{tabular}{llcc}
\hline & & N & Percentage \\
\hline Smoking before sleeping & Yes & 3 & $5.66 \%$ \\
\hline Alcohol consumption & No & 50 & $94.34 \%$ \\
\hline & Yes & 0 & $0.00 \%$ \\
\hline Disturbing noises before sleeping & No & 53 & $100.00 \%$ \\
\hline & Yes & 20 & $37.74 \%$ \\
\hline Lights off during sleeping & No & 33 & $62.26 \%$ \\
\hline & Yes & 18 & $33.96 \%$ \\
\hline Sleeping in bedroom & No & 35 & $66.04 \%$ \\
\hline Sleeping companion & Yes & 47 & $88.68 \%$ \\
\hline Television in bedroom & No & 6 & $11.32 \%$ \\
\hline & Yes & 40 & $75.47 \%$ \\
\hline
\end{tabular}

\section{CONCLUSION}

There was a high prevalence of high blood pressure and high blood glucose level in people of Morangan. There was a significantly positive correlation between systolic blood pressure and sleep duration, but there was no significant correlation between fasting blood glucose and sleeping duration. There was also a significantly positive correlation between systolic blood pressure and fasting blood glucose. The major disturbing sleep habits of Morangan people were caffeine consumption and heavy bedtime activities. This information will help to form a fitting education program towards Morangan people in treating and preventing hypertension and type 2 diabetes.

\section{REFERENCES}

Adams, R.J., 2010. Improving health outcomes with better patient understanding and education. Risk Management and Healthcare Policy,.

Aggarwal, S., Loomba, R.S., Arora, R.R., Molnar, J., 2013. Associations between sleep duration and prevalence of cardiovascular events. Clinical Cardiology, 36(11), 671-676.

Amalina, S., Sitaresmi, M.N., Gamayanti, I.L., 2016. Hubungan Penggunaan Media Elektronik dan Gangguan Tidur. Sari

\section{Pediatri, 17(4), 273.}

Badan Penelitian dan Pengembangan Kesehatan Kementrian Kesehatan RI, 2018. Riset Kesehatan Dasar.

Becker, N.B., De Jesus, S.N., Marguilho, R., Viseu, J., Rio, K.A.D., Buela-Casal, G., 2015. Sleep quality and stress: a literature review, in: Milcu, M., Gaspar de Matos, M., Vasilescu, I.P. (Eds.), Advanced Research in Health, Education and Social Sciences: Towards a Better Practice. Editora Universitária, 53-61.

Chaput, J.P., Dutil, C., Sampasa-Kanyinga, H., 2018. Sleeping hours: What is the ideal number and how does age impact this? Nature and Science of Sleep, 10, 421430.

Girschik, J., Heyworth, J., Fritschi, L., 2012. Reliability of a sleep quality questionnaire for use in epidemiologic studies. Journal of epidemiology, 22(3), 244-50.

Grandner, M.A., Jackson, N.J., Pak, V.M., Gehrman, P.R., 2012. Sleep disturbance is associated with cardiovascular and metabolic disorders. Journal of Sleep Research, 21(4), 427-433.

Hirshkowitz, M., Whiton, K., Albert, S.M., Alessi, C., Bruni, O., DonCarlos, L., Hazen, N., Herman, J., Adams Hillard, 
P.J., Katz, E.S., Kheirandish-Gozal, L., Neubauer, D.N., O'Donnell, A.E., Ohayon, M., Peever, J., Rawding, R., Sachdeva, R.C., Setters, B., Vitiello, M. V., Ware, J.C., 2015. National Sleep Foundation's updated sleep duration recommendations: Final report. Sleep Health, 1(4), 233-243.

Lastra, G., Syed, S., Kurukulasuriya, L.R., Manrique, C., Sowers, J.R., 2014. Type 2 diabetes mellitus and hypertension: An update. Endocrinology and Metabolism Clinics of North America, 43(1), 103-122.

Lou, P., Chen, P., Zhang, L., Zhang, P., Chang, G., Zhang, N., Li, T., Qiao, C., 2014. Interaction of sleep quality and sleep duration on impaired fasting glucose: a population-based crosssectional survey in China. BMJ open, 4(3), e004436.

Morselli, L., Leproult, R., Balbo, M., Spiegel, K., 2010. Role of sleep duration in the regulation of glucose metabolism and appetite. Best practice \& research. Clinical endocrinology \& metabolism, 24(5), 687-702.

Simanjutak, T.D., Saraswati, L.D., Muniroh, M., 2018. Gambaran Kualitas Tidur Pada Penderita Diabetes Militus Tipe-2 di Wilayah Kerja Puskesmas Ngresep. Jurnal Kesehatan Masyarakat (eJournal), 6(1), 328-335.

St-Onge, M.-P., Grandner, M.A., Brown, D., Conroy, M.B., Jean-Louis, G., Coons, M., Bhatt, D.L., American Heart Association Obesity, Behavior Change, Diabetes, and Nutrition Committees of the Council on Lifestyle and Cardiometabolic Health; Council on Cardiovascular Disease in the Young; Council on Clinical Cardiology; and Stroke Council, 2016. Sleep Duration and Quality: Impact on Lifestyle Behaviors and Cardiometabolic Health: A Scientific Statement From the American Heart Association. Circulation, 134(18), e367e386.

Suhadi, R., Virginia, D.M., Setiawan, C.H., 2017. Association of Lipid Profiles with 10 Years Atherosclerotic Cardiovascular
Disease Risk: Study Among Subjects in Sleman District Yogyakarta Indonesia. Asian Journal of Pharmaceutical and Clinical Research, 10(12), 166.

Wang, Y., Mei, H., Jiang, Y.-R., Sun, W.-Q., Song, Y.-J., Liu, S.-J., Jiang, F., 2015. Relationship between Duration of Sleep and Hypertension in Adults: A MetaAnalysis. Journal of Clinical Sleep Medicine, 11(9), 1047-56. 